\title{
Steroidal Control Mechanism of Cell Proliferation in Mouse Uterine Epithelium
}

\author{
Junji KIMURA, TADAshi OBATA and Hiroji OKADA \\ Department of Obstetrics and Gynecology, \\ Kyoto Prefectural University of Medicine, \\ Hirokoji, Kawaramachi, Kamikyo-ku, Kyoto 602, Japan
}

\begin{abstract}
Synopsis
The percentage of labeled cells in the uterine luminal epithelium of cycling mice showed the different zonal distributions at each stage of estrous cycle after cumulative labeling with ${ }^{3} \mathrm{H}$-thymidine for $36 \mathrm{hr}$. It was estimated that the proliferating fraction in the epithelium at proestrus, estrus, metestrus, and diestrus was $100 \%, 100 \%, 40 \%$ and $5 \%$, respectively. The percentage of labeled cells in the uterine luminal epithelium of cycling mice treated with progesterone remained below $10 \%$ level for at least $20 \mathrm{hr}$ after injections of progesterone.

Total labeling was attained in the uterine epithelium of castrated mice by the administration of estradiol-17 $\beta$. On the other hand, the cell proliferation in the uterine epithelium of castrated mice treated with estradiol and progesterone was markedly suppressed and the percentage of labeled cells remained approximately at $35 \%$. The remaining cell population, however, still showed the mitotic potency when mice received estradiol.

It is suggested from this study that the effect of progesterone is to suppress the epithelial cell proliferation and transfer cells into resting cell fraction which is still evoked to proliferate as the effect of estradiol and that a key factor controlling epithelial proliferation in mouse uterus during the estrous cycle is proliferating fraction rather than cell cycle time.
\end{abstract}

The cell proliferation in the mouse uterine luminal epithelium is under control of ovarian hormones. Galand et al. (1967) concluded that the action of estrogen was directed only to reduce the cell cycle time mostly at the expense of the period of DNA synthesis. On the other hand, Epifanova (1966) suggested that estrogen not only shortened the cell cycle time at the expense of $S$ and $G_{1}$ periods but also triggered new cells into the cycle.

On the effect of progesterone, Tachi et al. (1972) reported that in ovariectomizedadrenalectomized rats, progesterone pretreat-

Received February 18, 1977. ment abolished the response of the uterine luminal epithelium to estradiol for at least $12 \mathrm{hr}$. Das and Martin (1973) and Martin et al. (1973) reported that the administration of progesterone suppressed the proliferation of mouse luminal epithelial cells by the early $\mathrm{G}_{1}$-phase blocking.

In our previous study (Kimura et al., 1976 b), it was reported that fraction of labeled mitoses (FLM) curves prepared from mice at different stages of estrus cycle gave isocyclic waves in uterine luminal cells. This suggested the possibility that proliferating cells in the uterine luminal epithelium would turn the cell cycle at a constant cell cycle time during the estrous cycle. In this study, 
we attempted to confirm the changes of proliferating fraction in the mouse uterine luminal epithelium during estrous cycle and also to evaluate the modes of action of estrogen and progesterone in cell proliferation using the cumulative labeling technique with tritiated thymidine.

\section{Materials and Methods}

\section{Steroids}

Estradiol-17 $\beta\left(\mathrm{E}_{2}\right)$ and progesterone $(\mathrm{P})$ were purchased from Sigma Chemical Co. Estradiol-17 $\beta\left(\mathrm{E}_{2}\right)$ was dissolved in saline containing $2 \%$ ethanol at a concentration of $100 \mathrm{ng} / \mathrm{ml}$. Progesterone $(P)$ was dissolved in sesame oil at a concentration of $10 \mathrm{mg} / \mathrm{ml}$.

\section{Animals}

Female mice of ICR strain, weighing $20-25 \mathrm{~g}$, 8-week-old were used. The mice were kept in the airconditioned room with artificial lighting from 8 a.m. to 8 p.m.

Cycling mice: The cycling mice were divided into two groups, group (C-O) and group (C-P). The vaginal smears were taken to confirm the cyclic changes of vaginal cytology before the experiment. Each stage of estrous cycle was histologically determined according to Iijima (1965).

Spayed mice: Under ether anesthesia, each ovary was extirpated via dorsal route. Six weeks after the ovariectomy, the mice were divided into three groups, group (S-E), $(\mathrm{S}-\mathrm{E}+\mathrm{P})$ and $(\mathrm{S}-\mathrm{E}+\mathrm{P}+\mathrm{E})$.

\section{Hormone treatment}

Group (C-P) received four consecutive injections of $0.5 \mathrm{mg}$ of $\mathbf{P}$ as a single dose at 12 -hr intervals. Group (S-E) and group (S-E+P) received seven consecutive injections of $50 \mathrm{ng}$ of $\mathrm{E}_{2}$ or $50 \mathrm{ng}$ of $\mathrm{E}_{2}+$ $0.5 \mathrm{mg}$ of $\mathrm{P}$ as a single dose at 12-hr intervals, respectively. Group $(\mathrm{S}-\mathrm{E}+\mathrm{P}+\mathrm{E})$ received seven consecutive injections of $50 \mathrm{ng}$ of $\mathrm{E}_{2}+0.5 \mathrm{mg}$ of $\mathrm{P}$ and two additional consecutive injections of $50 \mathrm{ng}$ of $\mathrm{E}_{2}$ at 12 -hr intervals.

\section{Cumulative labeling with tritiated thymidine}

Tritiated thymidine $\left({ }^{3} \mathrm{H}-\mathrm{TdR}\right.$, specific activity $5.0 \mathrm{Ci} / \mathrm{m}$ mole) was obtained from New England Nuclear Co. The animals of each group received $1 \mu \mathrm{Ci} / \mathrm{g}$ body weight of ${ }^{3} \mathrm{H}-\mathrm{TdR}$ in saline as a single dose. All injections of ${ }^{3} \mathrm{H}-\mathrm{TdR}$ except intraperitoneal ones, $30 \mathrm{~min}$ prior to sacrifice, were intramuscularly given to cycling and spayed mice at $6-\mathrm{hr}$ or $5-\mathrm{hr}$ intervals.

Cycling mice: The mice of group (C-O) received multiple injections of ${ }^{3} \mathrm{H}-\mathrm{TdR}$ at 6-hr intervals for $36 \mathrm{hr}$. Group (C-P) received multiple injections of ${ }^{3} \mathrm{H}-\mathrm{TdR}$ at 5 -hr intervals from $36 \mathrm{hr}(0 \mathrm{hr}$ is the time of the first injection of steroids) to $56 \mathrm{hr}$.

Spayed mice: Group (S-E) and (S-E $+\mathrm{P})$ received cumulative injections of ${ }^{3} \mathrm{H}-\mathrm{TdR}$ at 5 -hr intervals from $50 \mathrm{hr}$ to $75 \mathrm{hr}$. Group $(\mathrm{S}-\mathrm{E}+\mathrm{P}+\mathrm{E})$ received multiple injections of ${ }^{3} \mathrm{H}-\mathrm{TdR}$ at 5 -hr intervals from $85 \mathrm{hr}$ to $105 \mathrm{hr}$.

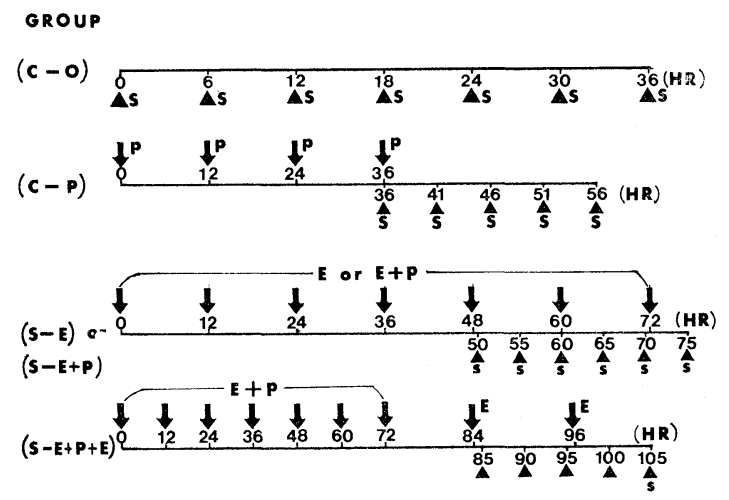

Fig. 1. Schedule of hormone treatment and cumulative labeling with ${ }^{3} \mathrm{H}$-thymidine.

$\Delta$ : mice are injected with $1 \mu \mathrm{Ci} / \mathrm{g}$ body weight of ${ }^{3} \mathrm{H}$-thymidine.

$\mathrm{s}$ : mice are sacrificed by cervical dislocation and sampling is performed.

$\downarrow$ : mice are injected with steroids.

E : mice are subcutaneously injected with $50 \mathrm{ng}$ of estradiol-17 $\beta$ as a single dose.

$\mathrm{E}+\mathrm{P}$ : mice are subcutaneously injected with $50 \mathrm{ng}$ of estradiol- $17 \beta$ and $0.5 \mathrm{mg}$ of progesterone as a single dose.

$P$ : mice are subcutaneously injected with $0.5 \mathrm{mg}$ of progesterone as a single dose.

Outlines of the hormone treatment and the cumulative labeling procedures are schematically shown in Fig. 1. The animals were sacrificed by cervical dislocation. The uterus was removed, fixed in Carnoy's fluid, embedded in paraffin, cross-sectioned at $4-5 \mu \mathrm{m}$, and coated with Sakura NR-M2 (Konishiroku Photo Ind., Co.) nuclear track emulsion. After autoradiographic exposure for 4 weeks at $4^{\circ} \mathrm{C}$, the slides were photographically processed and stained with hematoxylin and eosin (H-E). At least 1,000 uterine epithelial cells per mouse were counted from the 3-4 sections of the mid-region of each uterus to estimate the percentage of labeled cells. 


\section{Results}

\section{Cycling mice}

The percentage of labeled cells in the uterine luminal epithelium of group (C-O) showed different zonal distributions at each stage of estrous cycle. After cumulative labeling with ${ }^{3} \mathrm{H}-\mathrm{TdR}$ for $24 \mathrm{hr}$, the percentage of labeled cells in the epithelium of mice at proestrus and estrus attained approximately $100 \%$. The percentage of labeled cells in the epithelium of mice at metestrus and diestrus reached approximately to $40 \%$ and $5 \%$, respectively at $24 \mathrm{hr}$ (Fig. 2).
The percentage of labeled cells in the uterine luminal epithelium in group (C-P) remained under $10 \%$ level for $20 \mathrm{hr}$ after progesterone treatment (Fig. 3).

\section{Spayed mice}

The labeling index (LI) of the epithelial cells in group (S-E) at $50 \mathrm{hr}$ was $24 \%$ and thereafter increased lineally to $100 \%$ by $70 \mathrm{hr}$ (Fig. 4). The LI in group (S-E+P), however, was extremely low $(1-2 \%)$ at 50 $\mathrm{hr}$ and remained approximately $35 \%$ at 75 hr (Fig. 5). In group (S-E+P+E), almost all the luminal epithelial cells were labeled $20 \mathrm{hr}$ after cumulative labeling with ${ }^{3} \mathrm{H}$ TdR (Fig. 4).

\section{Labeled Cell (\%)}

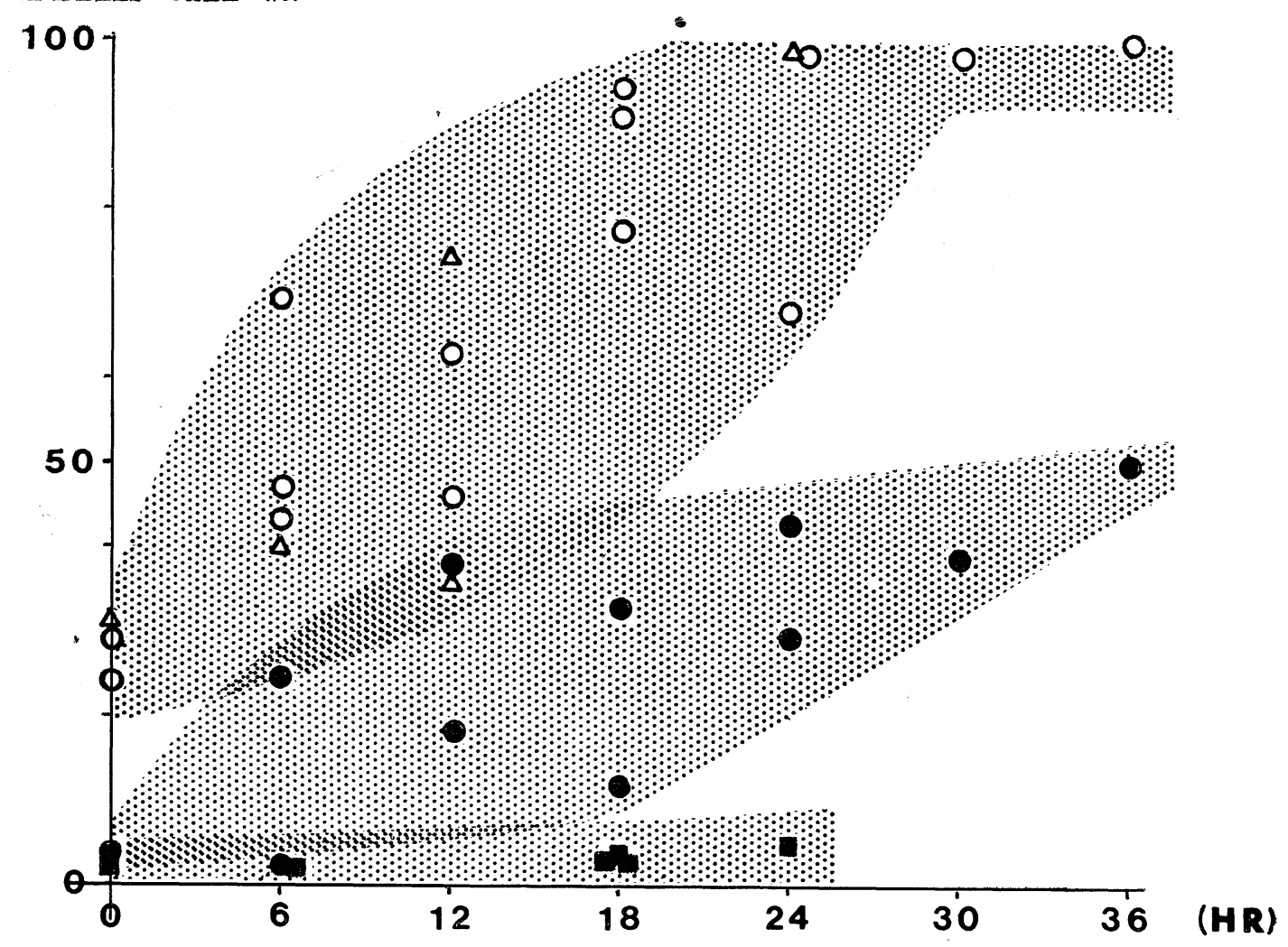

Fig. 2. The percentage of labeled cells in uterine luminal epithelum of cycling mice showed zonal distributions at each stage of estrous cycle after cumulative labeling with ${ }^{3} \mathrm{H}$-thymidine. Each symbol represents one animal.
$\triangle:$ proestrus
$\bigcirc:$ estrus
: metestrus
: diestrus 


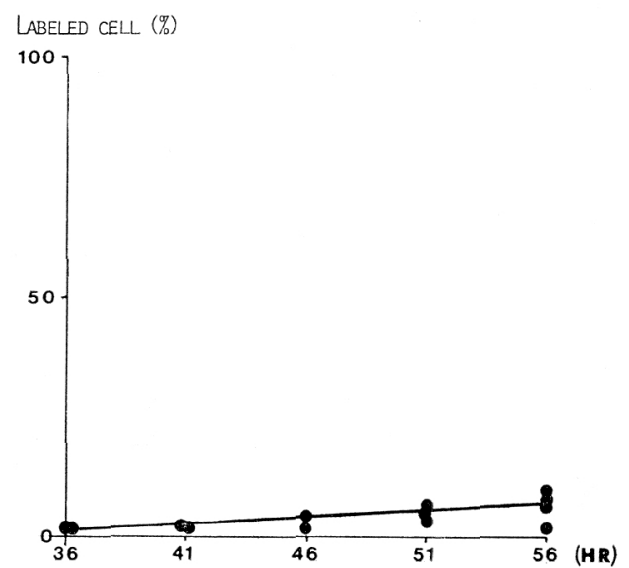

Fig. 3. Cycling mice received $0.5 \mathrm{mg}$ of progesterone at 12-hr intervals. Thirty-six hr after progesterone pretreatment, mice were injected multiply with $1 \mu \mathrm{Ci} / \mathrm{g}$ body weight of ${ }^{3} \mathrm{H}$-thymidine for $20 \mathrm{hr}$. The percentage of labeled cells in uterine luminal epithelium remained under $10 \%$ for $20 \mathrm{hr}$ after progesterone treatment. Each symbol represents one animal.

Table 1. Proliferating fractions in the uterine luminal epithelia of cycling and castrated mice

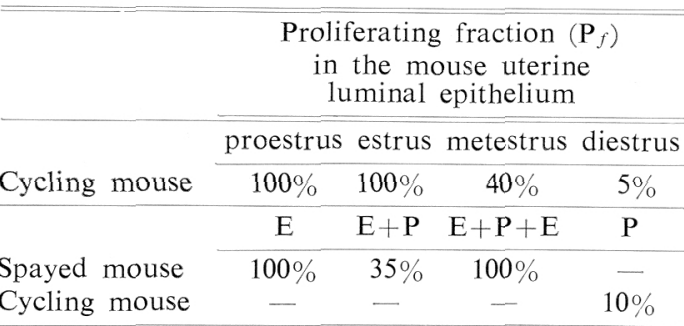

Proliferating fraction $\left(\mathrm{P}_{f}\right)$ in the uterine luminal epithelium of cycling and spayed mice is summarized based on the result obtained from cumulative labeling with ${ }^{3} \mathrm{H}$-thymidine.

E : mice treated with $50 \mathrm{ng}$ of estradiol-17 $\beta$ as a single dose.

$\mathrm{E}+\mathrm{P}$ : mice treated with $50 \mathrm{ng}$ of estradiol $-17 \beta$ and $0.5 \mathrm{mg}$ of progesterone as a single dose.

$\mathrm{E}+\mathrm{P}+\mathrm{E}:$ mice treated with $50 \mathrm{ng}$ of estradiol-17 $\beta$ and $0.5 \mathrm{mg}$ of progesterone followed by treatment with $50 \mathrm{ng}$ of estradiol-17 $\beta$.

$\mathrm{P}$ : mice treated with $0.5 \mathrm{mg}$ of progesterone as a single dose.

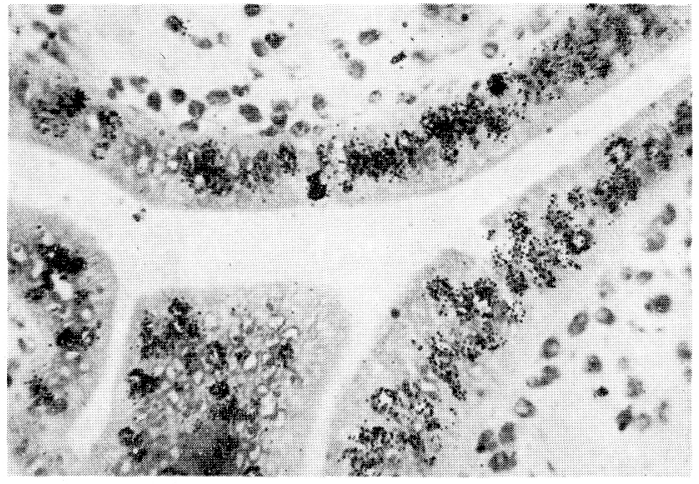

Fig. 4. ${ }^{3} \mathrm{H}$-thymidine autoradiography, $20 \mathrm{hrs}$ after cumulative labeling with ${ }^{3} \mathrm{H}$-thymidine, showed total labeling in uterine luminal epithelium of a representative mouse in group $(\mathrm{S}-\mathrm{E}+\mathbf{P}+\mathbf{E})$. Stained with $\mathrm{H}-\mathrm{E}, \times 400$.

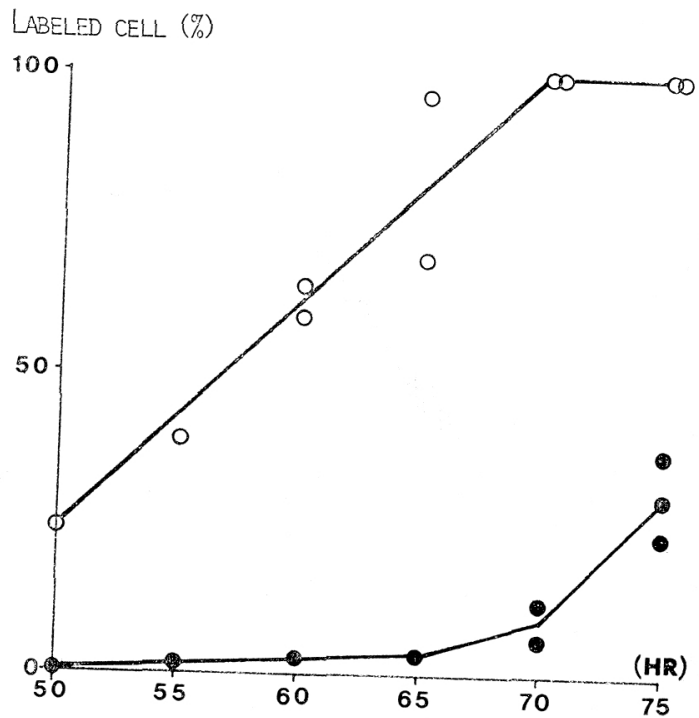

Fig. 5. The percentage of labeled cells in uterine luminal cells in group (S-E) and group $(S-E+P)$.

$O$ : each mouse in group (S-E) received $50 \mathrm{ng}$ of estradiol-17 $\beta$ as a single dose.

- : each mouse in group $(\mathrm{S}-\mathrm{E}+\mathrm{P})$ received $50 \mathrm{ng}$ of estradiol- $17 \beta$ and $0.5 \mathrm{mg}$ of progesterone as a single dose. 
An estimated proliferating fraction (Pf) in the uterine luminal epithelia of cycling and castrated mice was summarized on Table 1. A steroidal control mechanism of cell proliferation in mouse uterine epithelium is schematically presented (Fig. 6).

\section{Discussion}

The cumulative labeling method (Fujita, 1962) is one of the most valid techniques to analyze proliferation in tissue such as endometrium where hormonal stimulation as well as inhibition of proliferation may take place cyclically. DNA synthesis in the epithelial cells in castrated mice occurs $10-12 \mathrm{hr}$ after the injection of estrogen (Perrota, 1962; Kimura et al., 1976 b) and total labeling is obtained within $20 \mathrm{hr}$ after injections of estradiol (Kimura et al., 1976 b; Kimura et al., 1976 c). It means that epithelial proliferation evoked by estrogen will be well detected by cumulative labeling for $20 \mathrm{hr}$. Additionally, a possible effect of progesterone is ascribable to early $\mathrm{G}_{1}$-phase blocking (Das and Martin, 1973; Martin et al., 1973), so that all $\mathrm{G}_{1}$-blocked cells will be detected at least within the cell cycle time by this method. We reported in our previous studies (Kimura et al., 1976 b) that FLM curves prepared from mice at different stages of estrous cycle gave isocyclic waves in the uterine luminal cells and from these FLM curves TS (duration of DNA synthetic phase) and TC (cell cycle time) were $8.0 \mathrm{hr}$ and $13.5 \mathrm{hr}$, respectively.

In this study, the percentage of labeled cells in the uterine luminal epithelium of cycling mice showed the different zonal distributions at each stage of estrous cycle. The zonal, not lineal distributions of the percentage of labeled cells may reflect proliferating cell of luminal epithelium. Nevertheless, it is revealed that the proliferating fraction shows remarkable changes during estrous cycle. From these results and pre-

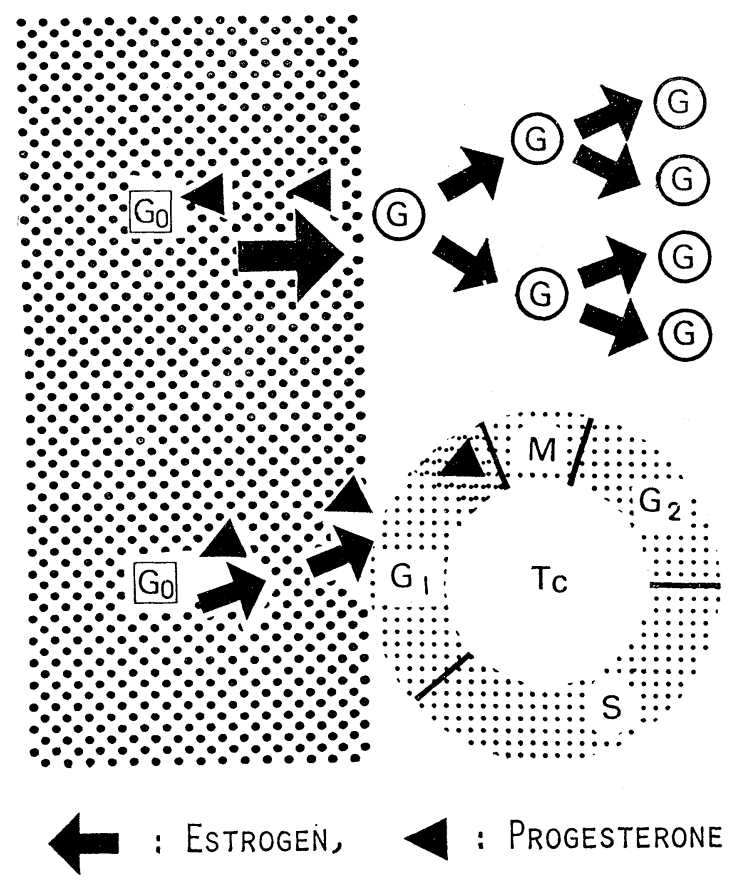

Fig. 6. Steroidal control mechanism of cell proliferation of mouse uterine epithelium: A schematic representation. Estradiol evokes proliferation by triggering resting cells $\left(\mathrm{G}_{0}\right.$ cells) into cell cycle. Progesterone suppresses epithelial proliferation by $\mathrm{G}_{1}-\mathrm{S}$ blocking and transfers generative cells ( $\mathrm{G}$ cells) into resting cell fraction.

vious data, it is assumed that epithelial proliferation during the estrous cycle depends primarily on the size of proliferating fraction rather than the cell cycle time.

Marked reduction in LI in the epithelial cells of mice treated with progesterone suggests two possibilities: one is that the epithelial cells remain at $G_{1}$-phase or are transformed into resting cells analogous to $\mathrm{G}_{0}$ cells (Lajtha, 1963) and the other is that the epithelial cells become differentiated cells which no longer undergo mitosis. The latter is unlikely because the proliferative potency of these cells is clearly demonstrated by the administration of estradiol in this study.

Kimura et al. (1976 a) have demonstrated that uterine luminal epithelial cells in progesterone-treated mice show an ultra- 
structural resemblance to $G_{0}$ cells in the castrated mice in which condensed perinuclear heterochromatin, very poorly developed rough endoplasmic reticulum, free ribosomes, and dense primary lysosomes are detected. It is proposed from our studies that progesterone suppresses proliferative cells by $\mathrm{G}_{1}-\mathrm{S}$ blocking and transfers them into $\mathrm{G}_{0}$ cell fraction and estrogen, on the other hand, stimulates cell proliferation by transferring $G_{0}$ cells into proliferative cell fraction.

\section{Acknowledgements}

The authors are grateful to Miss Anvette, University of New York at Buffalo General Hospital, for preparing this manuscript.

\section{References}

Das, R. M. and L. Martin (1973). J. Endocrinol. 59, 205.

Epifanova, O. I. (1966). Exp. Cell. Res. 42, 562.

Fujita, S. (1962). Exp. Cell Res. 28, 52.

Galand, P., F. Rodesch, F. Leroy and J. Chretien (1967). Exp. Cell Res. 48, 595.

Iijima, H. (1965). J. Jap. Obst. Gynec. Soc. 17, 433. (in Japanese)

Kimura, J., T. Obata and H. Okada (1976a). $J$. Clin. Electron Microscopy 9 1-2, 133.

Kimura, J., T. Obata and H. Okada (1976 b). Endocrinol. Japon. 23, 391.

Kimura, J., T. Obata and H. Okada $(1976$ c). Endocrinol. Japon. 23, 401.

Lajtha, L. G. (1963). J. Cell Comp. Physiol. 62 (Suppl. 1), 143.

Martin, L., R. M. Das and C. A. Finn (1973). J. Endocrinol. 57, 549.

Perrota, C. A. (1962). Am. J. Anat, 111, 195.

Tachi, C., S. Tachi and H. R. Lindner (1971). J. Reprod. Fert. 31, 59. 